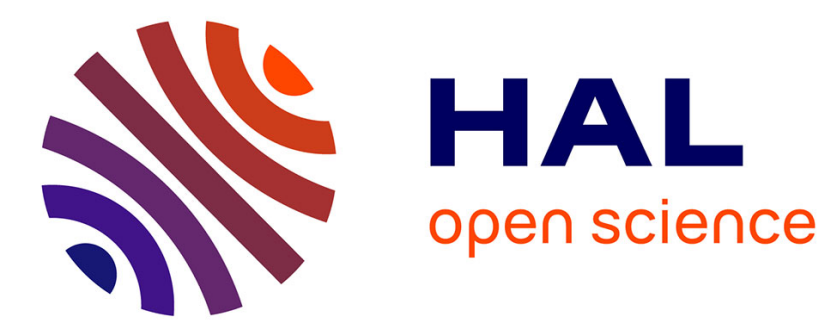

\title{
Tectono-stratigraphic history of the southern Junggar basin: seismic profiling evidences
}

Shengli Wang, Yan Chen, Julien Charreau, Dong-Tao Wei, Dong Jia

\section{To cite this version:}

Shengli Wang, Yan Chen, Julien Charreau, Dong-Tao Wei, Dong Jia. Tectono-stratigraphic history of the southern Junggar basin: seismic profiling evidences. Terra Nova, 2013, 25 (6), pp.490-495. $10.1111 /$ ter. 12063 . insu-00852430

\section{HAL Id: insu-00852430 \\ https://hal-insu.archives-ouvertes.fr/insu-00852430}

Submitted on 29 Oct 2013

HAL is a multi-disciplinary open access archive for the deposit and dissemination of scientific research documents, whether they are published or not. The documents may come from teaching and research institutions in France or abroad, or from public or private research centers.
L'archive ouverte pluridisciplinaire HAL, est destinée au dépôt et à la diffusion de documents scientifiques de niveau recherche, publiés ou non, émanant des établissements d'enseignement et de recherche français ou étrangers, des laboratoires publics ou privés. 


\title{
Tectono-stratigraphic history of the southern Junggar basin: seismic profiling evidences
}

\author{
Sheng-Li Wang ${ }^{1}$, Yan Chen ${ }^{2}$, Julien Charreau ${ }^{3}$, Dong-Tao Wei ${ }^{4}$, and Dong Jia ${ }^{1}$ \\ ${ }^{1}$ State Key Laboratory for Mineral Deposits Research, Department of Earth Sciences, Nanjing \\ University, Nanjing 210093, China \\ ${ }^{2}$ Univ d'Orléans, ISTO, UMR 7327, 45071, Orléans, France and CNRS/INSU, ISTO, UMR 7327, \\ 45071 Orléans, France and BRGM, ISTO, UMR 7327, BP 36009, 45060 Orléans, France \\ ${ }^{3}$ Centre de Recherche Pétrographique et Géochimique, 15 rue Notre Dame des Pauvres, B.P. 20, \\ 54501 Vandoeuvre lès Nancy, France \\ ${ }^{4}$ PetroChina Research Institute of Petroleum Exploration and Development-Northwest, Lanzhou
} 730020, China

Correspondence details

Sheng-Li Wang PhD

E-mail:wangslv@nju.edu.cn

Fax number: 00-86-25-83686016

Telephone number: 00-86-25 -89680700

Running title: Tectono-stratigraphic history of the southern Junggar basin 


\section{ABSTRACT}

The modern Tianshan is an active intracontinental range in central Asia. Its initial timing is poorly known and still hotly debated. As the subsidence of foreland basins is intrinsically coupled with the uplift of orogenic wedges, the foreland sedimentary records may accurately constrain the Tianshan uplifting history. To better address the question, we analyze a seismic profile across the southern Junggar foreland basin to decipher its tectonic and stratigraphic history. Four structural layers can be identified in an ascending order: the Permian - Lower Jurassic transtension-related layer, the Jurassic - Cretaceous thermal-subsistence layer, the Paleogene layer and the MioceneQuaternary foreland sedimentary layer. The oldest sedimentary sequence in the foreland succession is of the Shawan Formation deposited at $~ 24$ Ma based on magnetostratigraphic constraints. This indicates that foreland deformation in the northern Tianshan and uplifting of the modern Tianshan probably initiated at the beginning of the Miocene.

\section{Introduction}

Central Asia resulted from the accretion of several island arc terranes during the Paleozoic. However, the entire region was reactivated by a late Cenozoic deformation due to the India-Asia collision (e.g. Molnar and Tapponnier, 1975; Tapponnier and Molnar, 1979), which probably started $\sim 55 \mathrm{Ma}$ ago (e.g. Patriat and Achache, 1984). The present and recent deformation related to this collision has been widely studied during the last decades (e.g. Avouac et al., 1993; Yin, 2010). However, the timing of the tectonic reactivation and related building of the topography remain a matter of intense debate. This is particularly true for the modern Tianshan, representing a major 
component of this intracontinental deformation. This range, with impressive topography, may accommodate 10 to $20 \%$ of the total convergence between India and Asia, as shown by GPS measurements (Wang et al., 2001). A large temporal range has been obtained, based on different methods, from the late Oligocene (Hendrix et al., 1994; Dumitru et al., 2001; Sobel et al., 2006; Heermance et al., 2007; Ji et al., 2008) to the middle to late Miocene (Avouac et al., 1993; Metivier and Gaudemer, 1997; Bullen et al., 2001), or even to the latest Cenozoic or the Quaternary (Burchfiel et al., 1999). Many of these studies worked on limited section(s), rather than on a scale of the foreland basin. The discrepancy in the timing probably relates to the various geologic records across the mountains encountered by different authors and a lack of comprehensive work on the foredeep sedimentary sequences in the foreland basins. Modeling studies show that the infill of a retro-foreland or retro-arc foreland basin can directly record the mountain-building process of the coupling orogenic belt (Sinclair and Naylor, 2008; Sinclair and Naylor, 2012). Therefore, the foredeep sequences present a key to understand the uplifting history of the modern Tianshan.

In recent decades, the hydrocarbon exploration, with numerous high-quality seismic profiles, has been carried out in the northern and southern Tianshan foreland areas, presenting opportunities to study the onset of foreland tectonics and sedimentation along with uplifting of the modern Tianshan. We present here a long NE-SW seismic profile across the southern Junggar basin in the northern Tianshan foreland. We analyze the stratigraphic records as well as the structure of the foreland basin, in an attempt to decipher its tectono-stratigraphic history. Then, we discuss the timing when the southern Junggar basin acts as a foreland basin in response to uplifting of the modern Tianshan. 


\section{Geologic setting}

The modern Tianshan Mountains in central Asia extends along an east-west strike and across Xinjiang of western China, Kazakhstan and Kyrgyzstan. This range originated from accretion of several island arcs and collision of several continental blocks in the Paleozoic (Charvet et al., 2011), with a large-scale dextral strike-slipping event in Permian time (Bazhenov et al., 1999; Wang et al., 2007; Choulet et al., 2011). In the Mesozoic, the Tianshan was slightly reactivated, probably in response to accretion in the southern margin of the Asian continent, especially in the Tibetan area (Zhang et al., 2012), as attested by fission tracks analysis of granite (Jolivet et al., 2010), sedimentary deposits in the foreland area (Hendrix et al., 1992) and transpressional deformation in the northeastern Tarim (Wang et al., 2012). In the late Cenozoic, the Tianshan rejuvenated as an intracontinental orogen. The elevation of the modern Tianshan induced subsidence of the southern Junggar basin and the northern Tarim basin in a foreland environment.

In the northern Tianshan piedmont the foreland basin is actively deformed and three main rows of folds could be distinguished from surface geology and morphology (Avouac et al., 1993) in the west of Urumqi (Fig. 1). Since the Permian, the southern Junggar basin was deposited in a fluvio-lacustrine environment and mainly consists of mudstone, sandstone and conglomerate. Cenozoic sedimentary rocks in the basin include in an ascending order: the Ziniquanzi, Anjihaihe, Shawan, Taxihe, Dushanzi and Xiyu Formations (BGMRX, 1993), which have been well dated using magnetostratigraphic method (Charreau et al., 2009).

\section{Interpretation of the seismic profile across the northern Tianshan foreland area}


Figure 2 presents a $140-\mathrm{km}$-long and 4-second-deep seismic profile across the northern Tianshan piedmont. We use VSP and sonic logging data and the stratigraphic boundaries located by drilling holes to define the relationship between stratigraphic boundaries and seismic reflectors and then introduce them to other parts of the seismic profile by tracking and comparing of seismic reflectors. We pay particular attention to possible thickness variations of the strata that may reveal growth of tectonic structures or variations of deposition centers. In the seismic profile, we also analyze the structure and, in particular, identify several high-angle normal faults and a thrust.

\section{Styles and distribution of faults}

In the seismic profile (Fig. 2), we identified two types of faults which were active in two different phases. In the lower part of the seismic profile, seven high-angle normal faults ( $\mathrm{Fr} 1$ to $\operatorname{Fr} 7)$ extending downwards beyond the profile delimits a complicated 40-km large graben bounded by a high-angle NE-dipping fault Fr1 to the south and a SW-dipping fault Fr7 to the north. The hanging walls of both faults are mainly composed of the Permian and the lower Triassic rocks, and their foot walls are of Carboniferous tuff and metamorphic rocks. The vertical offset along fault Fr1 represents the thickness of the Permian to the Triassic layers. The high-angle SW-dipping fault Fr2 penetrates upward to the lower Triassic layer. Both walls of fault Fr2 are composed of the lower Triassic, the Permian and the older strata. The vertical offset along fault Fr2 is $\sim 100$ microseconds ( $200 \mathrm{~m})$. Other five faults, compared with fault Fr2, have smaller offsets but similar characteristics and orientations. 
In the southwestern end of the seismic profile (Fig. 2), there exists a thrust Ft1. It occurs within a Jurassic coal bed, in its hanging wall form two arrays of growth anticlines, i.e. the Xihu and N-Xihu anticlines (Figs. 1 and 2).

In the upper part of the seismic profile (Fig. 2) seven high-angle normal faults (Fe1 to Fe6) penetrate Late Cenozoic sediments. SW-dipping fault Fe1 incises upwards the upper Xiyu Formation and downwards the bottom of the Paleogene. Both walls of fault Fe1 are composed of similar strata, including the Paleogene, Neogene and Quaternary. The maximum vertical offset along fault Fe1 is about 50 microseconds. A small antithetic high-angle normal fault exists in the southwest of fault Fe1. High-angle SW-dipping faults $\mathrm{Fe} 2$ and $\mathrm{Fe} 3$ are approximately parallel to each other. They penetrate the Cretaceous as well as the younger strata. The vertical offsets along faults $\mathrm{Fe} 2$ and $\mathrm{Fe} 3$ are no more than 50 microseconds. Other three high-angle normal faults, compared with faults Fe1, $\mathrm{Fe} 2$ and $\mathrm{Fe} 3$, have smaller offsets but similar characteristics and orientations.

\section{Thickness variations of formations}

The Permian and Triassic layers only appear in the complex graben bounded by faults Fr1 and Fr5 (Fig. 2). The upper Jurassic layers generally cover a far broader area than the complex graben but the lower Jurassic layers are also penetrated by the normal faults bounded the Permian-Triassic graben. The Jurassic in the southeastern segment of the seismic profile, buried beneath the Late Cenozoic fold and thrust belt, thins northeastwards, and pinches out to the northern Tianshan foredeep. Drilling reveals that the Jurassic layers consist of greenish gray and poorly-rounded conglomerate intercalated with grayish cobblestone. The Cretaceous exists 
throughout the profile, but its thickness varies laterally. The thinnest Cretaceous occurs in the southwest of fault Fr1, lying on the basement; the thickest in the centre of the graben. The Cretaceous consists of gray fine sandstone interbedded with argillaceous siltstone, and grayish green conglomerate at the bottom.

The Paleogene throughout the profile is relatively constant in thickness $(\sim 0.3$ second, $\sim 600 \mathrm{~m}$ (Fig. 2). Drilling reveals that the Paleogene consists of gray fine sandstone and argillaceous siltstone intercalated with gray mudstone.

The Miocene and Quaternary include the Shawan, Taxihe, Dushanzi and Xiyu Formations, and lap on the forebuldge from the proximal part of the foredeep, gradually thins, and finally pinches out at the distal part. These formations deposited a sedimentary prism in the northern Tianshan foreland with a maximum thickness of $\sim 5000 \mathrm{~m}$ in the foredeep (Figs. 1 and 2). Drilling and surface geology reveal that the lower member of the Shawan formation consists of gray sandy conglomerate, gravelly sandstone and medium-grained sandstone, intercalated with gray mudstone. The upper member of the Shawan Formation is composed of purplish red mudstone, intercalated with argillaceous siltstone, argillaceous sandstone, gray fine sandstone and gravelly fine sandstone. The Taxihe Formation consists of purplish red mudstone, intercalated with siltstone and gravelly sandstone in the bottom. Oil boreholes closing to the seismic profile indicate that the Shawan and Taxihe Formations obviously thin northwards and yet the Anjihaihe Formation lying below them remains relatively constant thickness (Liu, 2010). The Dushanzi Formation is composed of gray mudstone, intercalated with light gray argillaceous siltstone, while the Xiyu Formation consists of gray conglomerate. 
The bottoms of the Shawan, Taxihe, Dushanzi and Xiyu Formations are dated at 23.6 Ma, $\sim 20.1 \mathrm{Ma}, \sim 16 \mathrm{Ma}$, and $7.5 \mathrm{Ma}$ respectively constrained by magnetostratigraphic studies (Charreau et al., 2009). We therefore extrapolate the west segment of the foredeep through cross-track seismic profile (Figs. 3 and S1) to construct a time frame of the identified seismic reflectors.

\section{Discussion}

Based on the present tectonics and stratigraphy between the modern Tianshan and the Junggar basin (Figure 2), four structural layers can be identified in the basin in an ascending order: the Permian - Lower Jurassic transtension-related layer, the Jurassic - Cretaceous thermal-subsistence layer, the Paleogene layer and the Miocene - Quaternary foreland sedimentary layer.

\section{Pre-Miocene history}

The Permian - Lower Jurassic transtension-related tectonic layer is limited within the graben bounded by the high-angle normal faults, and should have been deposited in an extensional environment. This extensional environment should be part of a first-order transtensional or extensional tectonics. Paleomagnetic studies (Bazhenova et al. 1999; Wang et al., 2007; Choulet et al., 2011) reveal that dextral transtensional shearing occurred in this area from Early Permian to Early Jurassic time.

The upper part of the Jurassic - Cretaceous is thicker in the central part of the graben, and thinner in both flanks. This layer was deposited in a relatively quiet tectonic environment that was probably related to thermal subsidence of the transtensional basin during the Early Permian - Early 
Jurassic. The Jurassic on the northern shoulder of the graben (above the Fr7 and beneath Fe5) was locally eroded and covered unconformably by the Lower Cretaceous. This may be related to differential compact of the Permian - Lower Jurassic to form a local high on the northern shoulder of the graben. Nevertheless, the relatively thick deposits of the Jurassic in the southern segment of Figure 2 seem to imply that weak uplifting of the Mesozoic Tianshan induced low-amplitude subsidence of the foreland area (Jolivet et al., 2012).

The Paleogene Ziniquanzi and Anjihaihe Formations present a relatively constant thickness in the seismic profile. Seismic profiling indicates that the Paleogene sediments in the Tarim basin (Zhang et al., 2004) and the Qaidam basin (Wang et al., 2008) share a similar style as well, indicating that the Paleogene was a tectonically quiet interval, probably responding to dynamic subsidence induced by subduction of the Indian plate beneath the Asian plate.

\section{Nature of the northern Tianshan foreland basin and its implications for uplifting time of the}

\section{Tianshan}

The northern Tianshan foreland basin distinguishes itself from either classic retro-arc foreland, pro-foreland, or retro-foreland basins in that it is far away from a coeval orogenic belt. It may be classified into the east-northeast-dipping subduction-related foreland basin supposed by Doglioni (1994). Wide angle seismic reflection/refraction profiling and magnetotelluric probing demonstrate that the Tarim block underthrusts beneath the overriding Junggar block (Zhao et al., 2003). Therefore, such deep structure beneath the northern Tianshan foreland basin mimics the plate setting of a retro-foreland basin (Naylor and Sinclair, 2008). Consequently, the initiation of the 
modern Tianshan can be appreciably derived from the stratigraphic architecture of the northern Tianshan foredeep.

The sedimentary sequence of the Shawan Formation and the younger strata is a northwardly-thinning prism and deposition center of them during development of the foreland basin migrated weakly, representing features of the fill in a retro-foreland basin. The normal faults penetrating the foreland successions formed in the forebuldge which was under weak extension environment (DeCelles and Giles, 1996). While, active thrust Ft1 occurred in the proximal part of the fold-and-thrust belt under compression resulting from the Cenozoic Tianshan.

The oldest onlapping sequence in the bottom of the Shawan Formation, along with widespread lapping on the forebuldge recognized in the seismic profile (Fig. 2), represents more direct evidence of the modern Tianshan orogeny. This oldest onlapping contact is a sedimentary record indicative of the start of the foreland basin. Figure S1, connecting Figures 2 and 3, indicates that seismic reflectors are continuous and traceable in the basin. According to the magnetostratigraphic analysis, its age is $\sim 24 \mathrm{Ma}$ (Charreau et al., 2008; 2009). This means that the Paleozoic Tianshan orogen could have been rejuvenated to build the modern Tianshan at $~ 24$ Ma. However, we focus our analysis on the earliest stage of foreland processes when sediments are relatively distal in a relatively low relief setting, and, therefore, probably exhibit less lateral facies variations. Hence our extrapolation, even an approximate estimate, probably provides a relatively first order and realist timing constraint of the foreland processes recorded in the basin.

\section{Conclusions}


Based on interpretation of the seismic profile, the sedimentary sequences in the modern northern Tianshan foreland basin can be divided into the Permian - Early Jurassic transtension-related, the Jurassic - Cretaceous thermal subsidence, the Paleogene and the Pliocene Quaternary foreland layers. The former two tectonic layers are produced by transtension and following thermal subsidence in the Tianshan and adjacent area. The third uniform thickness layer indicates that the Junggar block experienced a relatively quiet tectonic period in the Paleogene time. As the sedimentary response to uplifting of the modern northern Tianshan, the base of MioceneQuaternary foreland sequences is the direct geologic record of the initial uplifting of the modern Tianshan. According to the magnetostratigraphic dating, we conclude that the initial uplifting of the modern Tianshan is at $\sim 24 \mathrm{Ma}$.

\section{Acknowledgements}

We thank the editor Carl Doglioni, An Yin, S. Dominguez and Mark Naylor for their thorough reviews and comments, which greatly improved the manuscript. The authors are grateful to K.J. Zhang, Dong-Lin Xu, and Huaizhi Xu for helpful discussion on interpreting of the seismic profiles. This work is supported by National Science Fountain of China (grant 49832040).

\section{References}

Avouac, J.P., Tapponnier, P., Bai, M., You, H., and Wang, G., 1993. Active thrusting and folding along the northern Tien-Shan and Late Cenozoic rotation of the Tarim relative to Dzungaria and Kazakhstan. J. Geophys. Res., 98, 6755-6804. 
Bazhenov, M.L., Burtman, V.S., and Dvorova, A.V., 1999. Permian paleomagnetism of the Tien Shan fold belt, Central Asia: post-collisional rotations and deformation. Tectonophysics, 312, 303-329.

Bullen, M.E., Burbank, D.W., Garver, J.I., Abdrakhmatov, and Ye K., 2001. Late Cenozoic tectonic evolution of the northwestern Tien Shan: New age estimates for the initiation of mountain building. Geol. Soc. Am. Bull., v. 113, p. 1544-1559.

Burchfiel, B. C., Brown, E. T., Q., Deng, Li, J., Feng, X., Molnar, P., Shi, J., Wu, Z., and You, H., 1999. Crustal shortening on the margins of the Tian Shan, Xinjiang, China. Int. Geol. Rev., 41, $663-700$.

BGMRX (Bureau of Geological and Mineral Resources of the Xinjiang Uygur Autonomous Region), 1993, Regional geology of Xinjiang Uygur Autonomous region, People's Republic of China Ministry of Geology and Mineral Resources, Geol. Mem., 32, 841 pp.

Charreau, J., Avouac, J.-P., Chen, Y., Dominguez, S., and Gilder, S., 2008. Miocene to present kinematics of fault-bend folding across the Huerguosi anticline, northern Tianshan (China), derived from structural, seismic, and magnetostratigraphic data. Geology, 36, 871-874..

Charreau, J., Chen, Y., Gilder, S., Barrier, L., Dominguez, S., Augier, R., Sen, S., Avouac J. P., Gallaud A., Graveleau, F., and Wang, Q., 2009. Neogene uplift of the Tian Shan Mountains observed in the magnetic record of the Jingou River section (northwest China). Tectonics, 28, TC2008, 1-22. 
Charvet, J., Shu, L.S., Laurent-Charvet, S., Wang, B., Faure, M., Cluzel, D., Chen, Y., De Jong, K., 2011. Paleozoic tectonic evolution of the Tianshan belt, NW China. Sci. China Earth Sci., 54, $166-184$.

Choulet, F., Chen, Y., Wang, B., Faure, M., Cluzel, D., Charvet, J., Lin, W. and Xu, B., 2011. Late Palaeozoic palaeogeographic reconstruction of Western Central Asia based upon paleomagnetic data and its geodynamic implications. J. Asian Earth Sci., .42, .867-884.

DeCelles, P.G. and Giles, K.A., 1996. Foreland basin systems. Basin Res., 8, 105-123.

Doglioni, C., 1994. Foredeeps versus subduction zones. Geology, 22, 271-274.

Dumitru, T. A., Zhou, D., Chang, E. Z., Graham, S. A., Hendrix, M. S., Sobel, E. R., and Caroll, A. R., 2001, Uplift, exhumation, and deformation in the Chinese Tian Shan, in Paleozoic and Mesozoic Tectonic Evolution of Central Asia: From Continental Assembly To Intracontinental Deformation, edited by M. S. Hendrix and G. A. Davis, in Geol. Soc. Am. Mem., 194, 71 - 99. Heermance, R. V., Chen, J., Burbank, D. W., Wang, C., 2007. Chronology and tectonic controls of late Tertiary deposition in the southwestern Tian Shan foreland, NW China. Basin Res., 19, 599 $-632$.

Hendrix, M. S., Graham, A. S., Carroll, A. R., Sobel, E. R., McKnight, C. L., Schulein, B. J., Wang, Z., 1992, Sedimentary record and climatic implications of deformation in the Tian Shan:

Evidence from Mesozoic strata of the north Tarim, south Junggar, and Turpan basins, northwest China. Geol. Soc. Am. Bull., 104, 53 - 79.

Hendrix, M. S., Dumitru, T. A., Graham, S. A., 1994. Late Oligocene-early Miocene unroofing in the Chinese Tian Shan: An early effect of the India-Asia collision. Geology, 22, 487-490. 
Ji, J., Luo, P., White, P., Jiang, H., Gao, L., Ding, Z., 2008. Episodic uplift of the Tianshan Mountains since the late Oligocene constrained by magnetostratigraphy of the Jingou River section, in the southern margin of the Junggar Basin, China. J. Geophys. Res., 113, B05102.

Jolivet, M., Dominguez, S., Charreau, J., Chen, Y., Li, Y., Wang, Q., 2010. Mesozoic and Cenozoic tectonic history of the central Chinese Tian Shan: reactivated tectonic structures and active deformation. Tectonics, 29, TC6019.

Liu, J., 2010, Study on the Sedimentary Systems of Neogene of Chepaizi Area in the Northwest Edge of Junggar Basin, [Master Thesis]: Dongying, China University of Petroleum (East China), $92 \mathrm{p}$.

Metivier, F., and Gaudemer Y., 1997. Mass transfer between eastern Tien Shan and adjacent basins (central Asia): Constraints on regional tectonics. Geophys. J. Int., .128,.1 - 17. .

Molnar, P., Tapponnier, P., 1975. Cenozoic tectonics of Asia: effects of a continental collision. Science, 189, 419-426.

Naylor, M. and Sinclair, H. D., 2008. Pro- vs. retro-foreland basins. Basin Res., 20, 285-303.

Patriat, P. A., and J. Achache, 1984. India-Eurasia collision chronology has implications for crustal shortening and driving mechanisms of plates. Nature, $311,615-621$.

Sobel, E. R., M. Oskin, D. Burbank, Mikolaichuk, A., 2006. Exhumation of basement-cored uplifts: Example of the Kyrgyz Range quantified with apatite fission track thermochronology. Tectonics, 25, TC2008.

Sinclair H.D. and Naylor M., 2012. Foreland basin subsidence driven by topographic growth versus plate subduction. Geol. Soc. Am. Bull., .124, 368-379. 
Tapponnier, P., Molnar P., 1979. Active faulting and Cenozoic tectonics of the Tien Shan, Mongolia and Baykal Regions. J. Geophys. Res., 84, 3425-3459.

Wang, B., Chen, Y., Zhan, S., Shu, L., Faure M., Cluzel, D., Charvet, J., Laurent-Charvet, S., 2007. Primary Carboniferous and Permian paleomagnetic results from the Yili Block (NW China) and their implications on the geodynamic evolution of Chinese Tianshan Belt. Earth Planet. Sci. Lett., .263, .288-308..

Wang, Q., Zhang, P.-Z., Freymueller, J.T. , Bilham, R., Larson, K. M., Lai, X., You, X., Niu, Z., Wu, J., Li, Y., Liu, J., Yang, Z., Chen, Q., 2001. Present-day crustal deformation in China constrained by global positioning system measurements. Science, .294, .574-7.

Wang, S., Li, W., Wei, D., Tan, Y., Lu, H, 2008. A kinematic model for the deformation of the Qaidam Basin since the Middle Miocene based on seismic data. J. Nanjing Univ. (Natural Sciences), 44, 25-41.

Wang, S.-L., Shu, L.-S., Zhu, W.-B., Xu, M.-J., Lu, H.-F., Xiao, Z.-Y., Luo, J.-C., Zhu, C.-J., 2012. Mesozoic faults in the NE Tarim (western China) and the implications on collisions in the southern Eurasian margin. J. Asian Earth Sci., 56, 191-199.

Yin, A., 2010. Cenozoic tectonic evolution of Asia: A preliminary synthesis. Tectonophysics, .488, 293-325.

Zhang, S., Huang, Z., and Zhu, H., 2004, Phanerozoic Strata of the Tarim Basin: Petroleum Industry Press, Beijing, p. 299.

Zhang, K.J., Zhang, Y.X., Tang, X.C., and Xia, B., 2012. Late Mesozoic tectonic evolution and growth of the Tibetan plateau prior to the Indo-Asian collision. Earth-Sci. Rev., 114, 236-249. 
Zhao, J., Liu, G., Lu, Z.,, Zhang, X., Zhao, G., 2003. Lithospheric structure and dynamic processes of the Tianshan orogenic belt and the Junggar basin. Tectonophysics, 376, 199-239.

\section{FIGURE CAPTIONS}

Fig. 1 (a) Shaded relief map and thickness contours (unit: meter) of the Neogene and Quaternary in the northern Tianshan foreland area. Index map indicates the location of the modern Tianshan intracontinental orogen in the frame of the India-Tibet collision system. The direction and velocity of the Indian tectonic plate is from Wang et al. (2001). Locations of Figs. 2, 3and S1 are marked with thick black lines. (b) Geological map of the Tianshan area (Charreau et al., 2009). NTSFZ, North Tianshan Fault Zone; STSFZ, South Tianshan Fault Zone.

Fig. 2 Uninterpreted (a) and interpreted (b) seismic profile across the northern Tianshan foreland. See Figure 1 for location. Vertical exaggeration is about 5X. Permian - Early Jurassic high-angle normal faults, a Late Cenozoic detachment fault and Late Cenozoic high-angle normal faults are identified.

Fig. 3 Corresponding relationship between the magnetostratigraphic ages and seismic reflectors. (a) Interpreted seismic profile; (b) Uninterpreted seismic profile. See Fig. 1 for location. The magnetostratigraphic column is from Charreau et al. (2008; 2009). The seismic profile is very close and parallel to the sampling locations of the magnetostratigraphic column.

\section{Supporting Information}

Additional Supporting Information may be found in the online version of this article: 
Figure S1. Cross-track seismic profiles connecting Figures 2 and 3. See Figure 1 for seismic profiles locations. In order to compare these seismic profiles, Figures 2 and 3 are presented here. In this assembly presentation, Figures 2, 3 and S1 share the same vertical scale; Figures 3 and S1 have the same horizontal scale but Figure 2. Figure S1 directly crosses Figure 2, but Figure 3. However, Figures S1 and 3 share comparable seismic facies and continuous seismic reflectors. Through Figure $\mathrm{S} 1$, the time frame of the Late Cenozoic along Figure 2 constructed by magnetostratigraphic analysis may be extended to Figure 2 . 
Figure 1
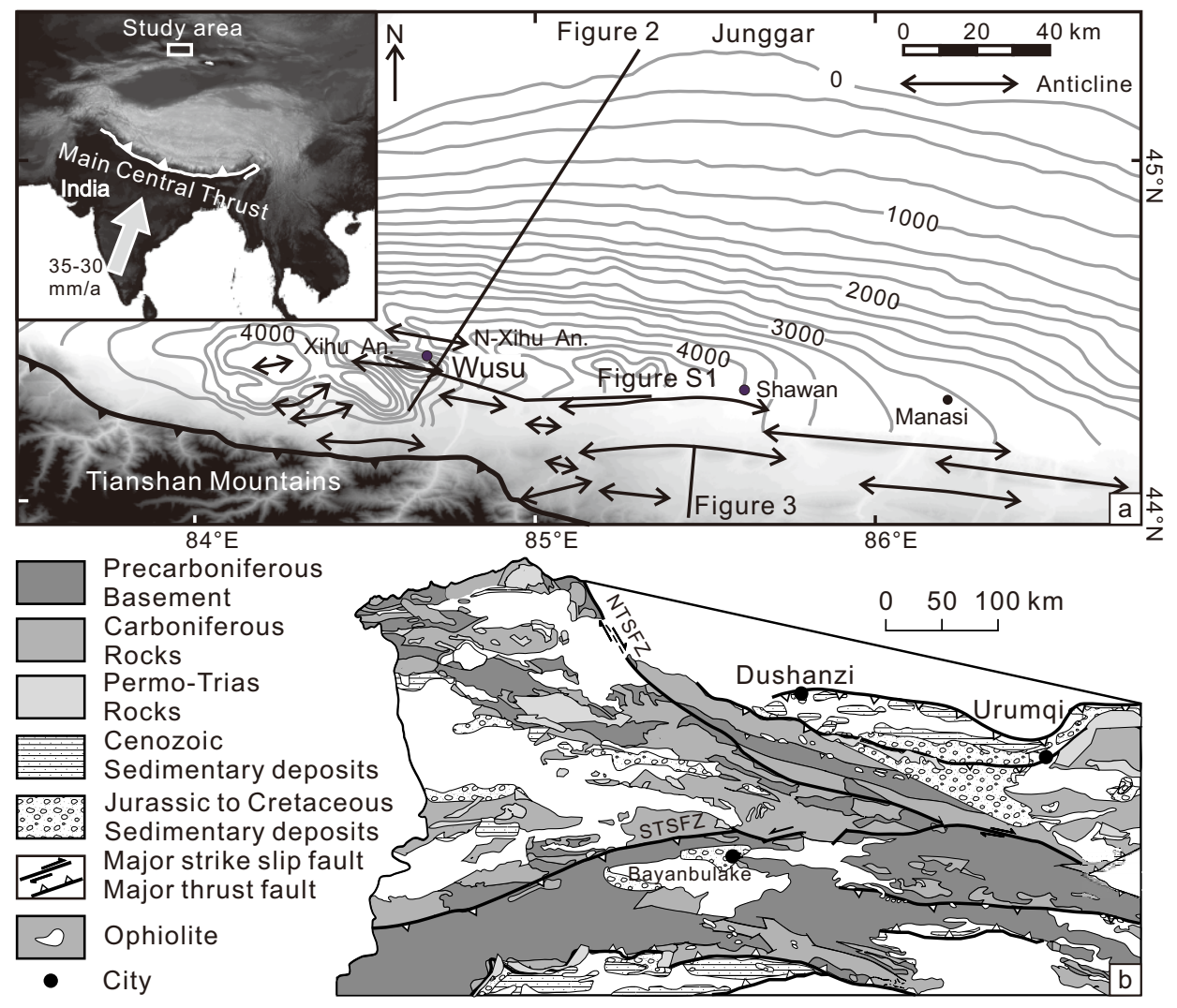

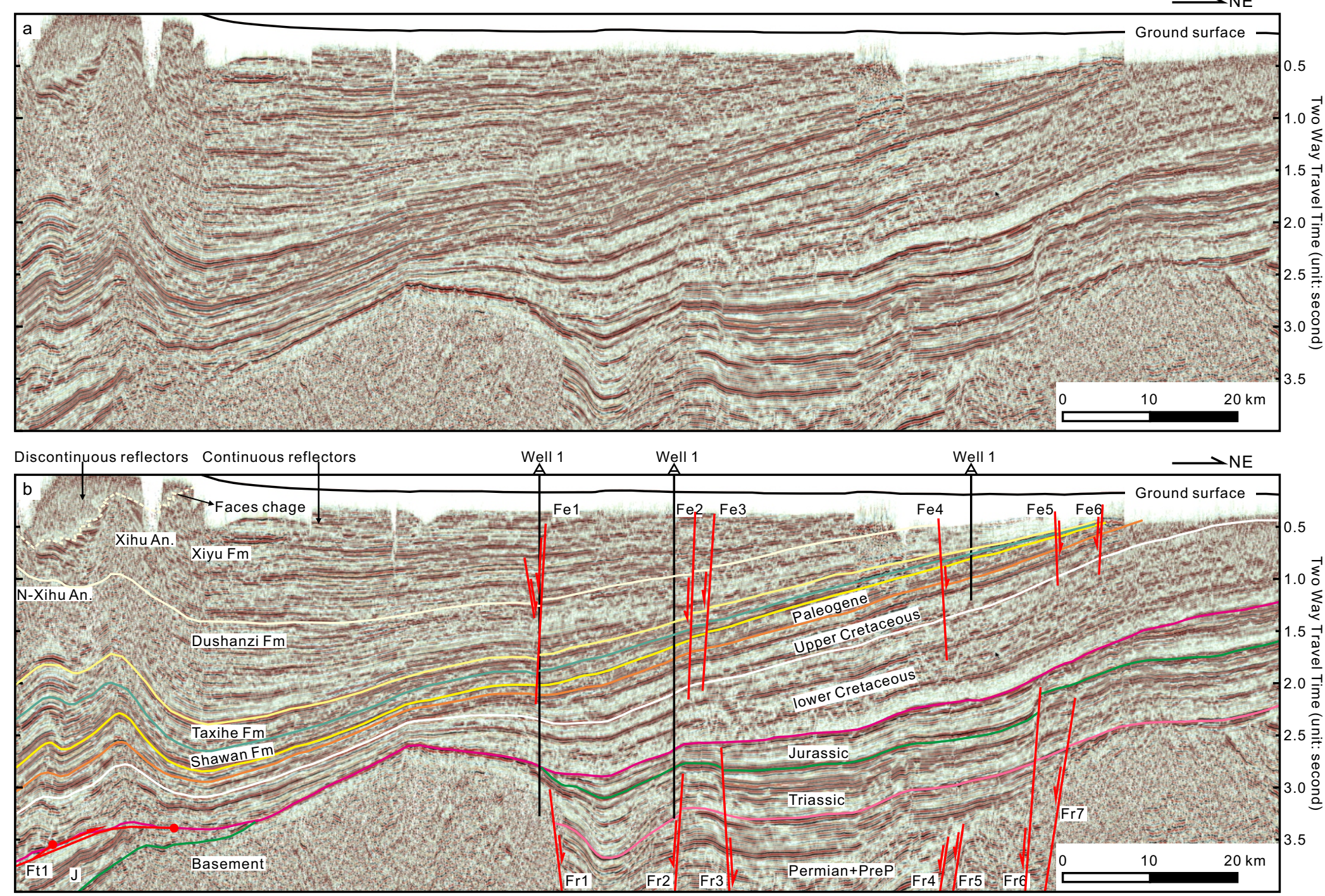
Figure 3
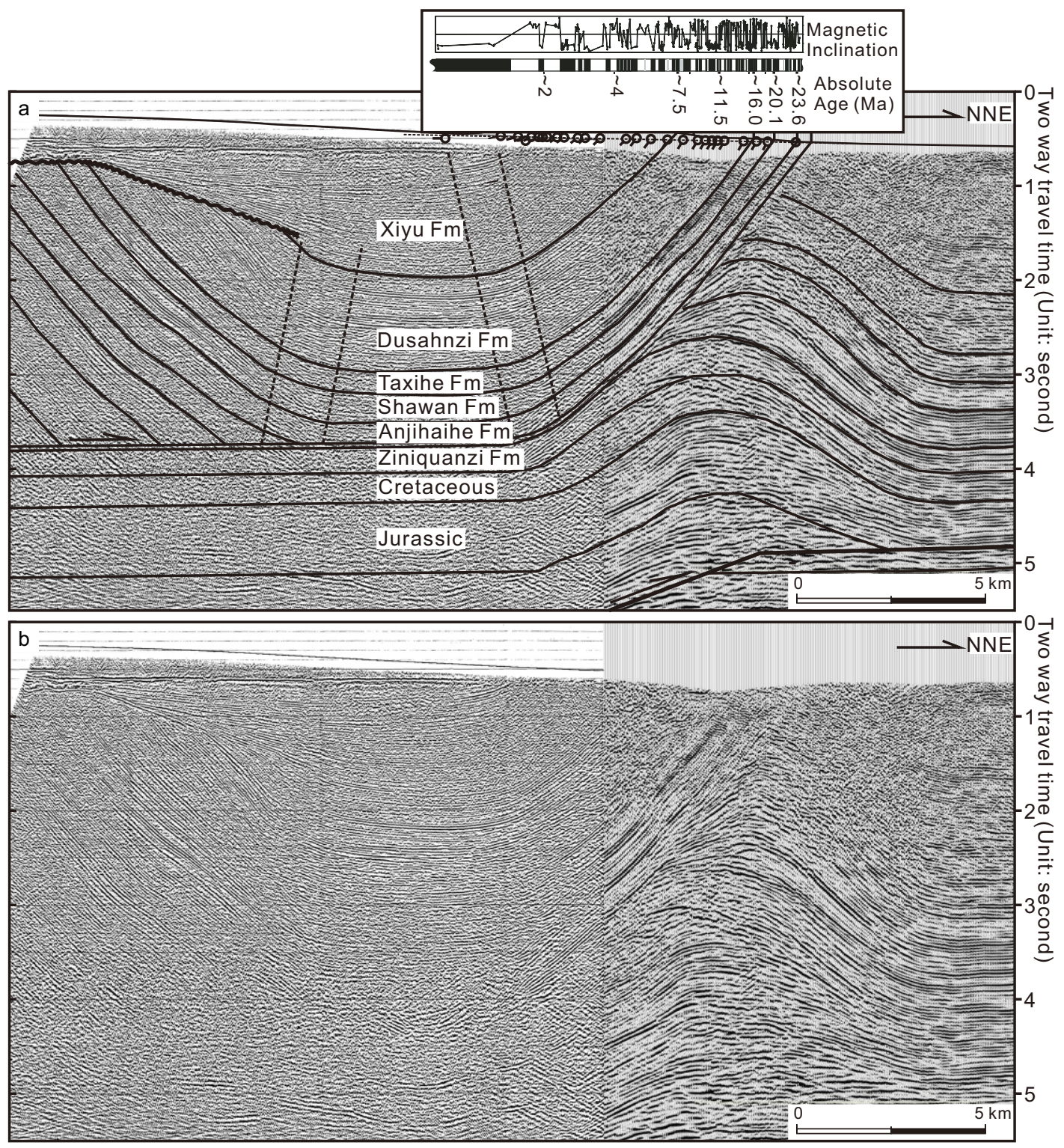

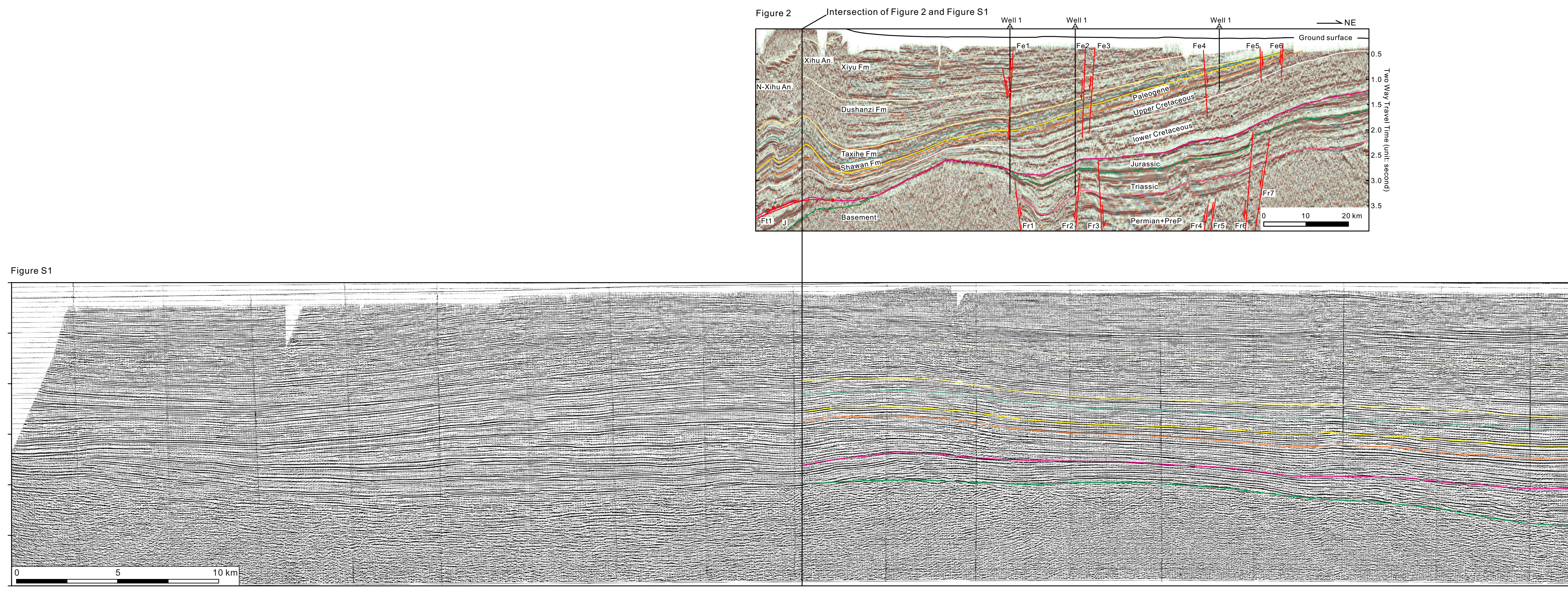

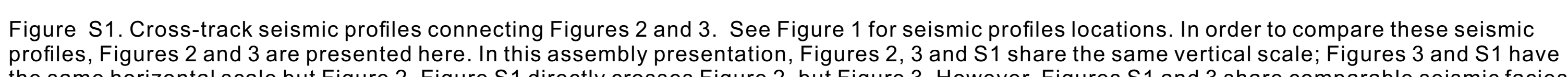

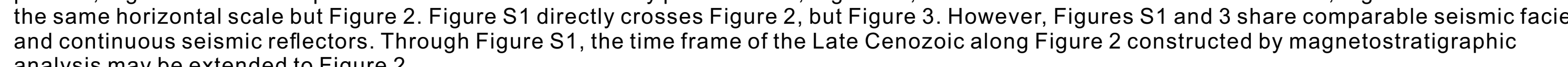

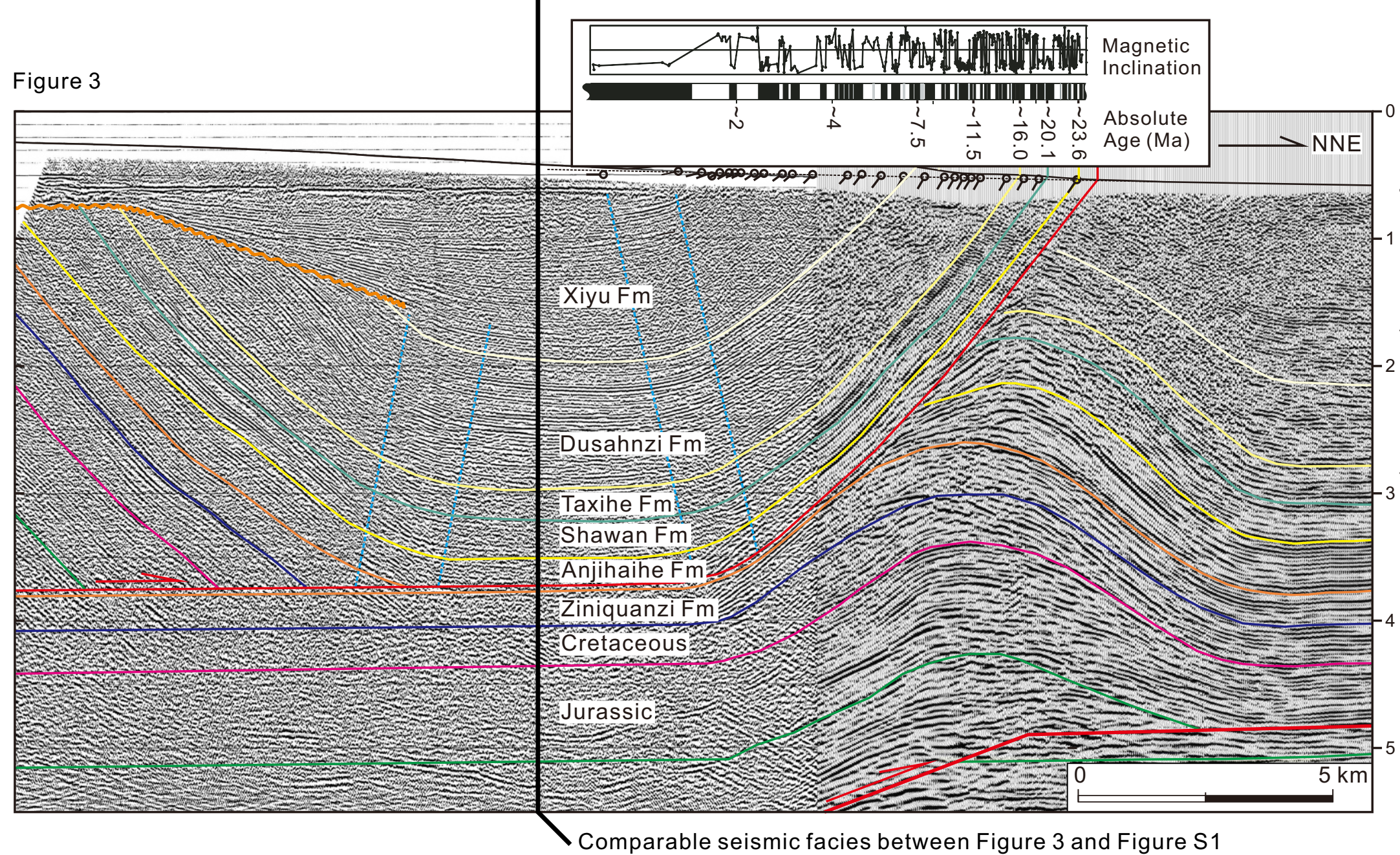

